\title{
ARTICLE
}

\section{Imagining Alternatives: The Educational and Public Nature of Assessment}

\author{
Viki L. Montera, Sonoma State University
}

\begin{abstract}
Assessment and accountability are words that have become synonymous with standardized testing. This view has narrowed the curriculum and limited the nature of learning and schooling experiences for children. This narrow focus has also driven educational practices away from ideas found in current learning theory. The following case study illustrates one school's effort to expand assessment and accountability activities, to bring assessment practices in line with recommendations in the learning and assessment research literature and to encourage dialogue throughout the school community regarding the school's program and students' learning. Using a narrative constructed from data from one of the
\end{abstract}

school's assessment activities, the author, who was also serving as the school principal at the time of the event, discusses the complexities and potential of making student learning public and involving the public in assessment. Creating a public forum to explore ideas and conceptions about schooling and learning among adults and children links school accountability to awareness and understanding of school purposes and pedagogy. This democratic aspect of assessment and accountability may hold power to influence school reform and imagine educational alternatives beyond the reliance and acceptance of standardized testing as the gold standard.
Imagination is not only the uniquely human capacity to envision that which is not, and therefore the fount of all invention and innovation. In its arguably most transformative and revelatory capacity, it is the power that enables us to empathize with humans whose experiences we have never shared.

- JK Rowling, 2008

In a review of 10 years of research on assessment, Broadfoot and Black (2004) state that it is "impossible to imagine" assessment processes in formal schooling that challenge prevailing current practices that are "born of the modernist assumptions and educational needs of the nineteenth century" (p. 20). Yet, that may just be what is required. According to Rowling, imagination provides a means for seeing possibilities different from those that we know. Heckman and Montera (2009), in their work on school reform, argue that imagination and invention are needed in the work of transforming our schools. They further state utilizing imagination provides opportunities for moving beyond our long accepted taken-for-granted "modernist assumptions" of the nineteenth century.

Assessment and accountability have become synonymous with standardized testing. This view ignores the broader meanings embedded in these two words. The negative implications of this narrow view of assessment and accountability on student learning and educational outcomes have been well documented and argued, including a narrowing of the curriculum to what is tested and students' misapprehension of their success as measured by the test. (Lemann, 1999; Koretz, 2008; McNeil, 
2000; Mintrop, Heinrich, \& Suderman, 2009; Ravitch, 2010; Sacks, 1999; Sirotnik, 2002; Smith, 2004). In 2001, Cizek looked closely at the testing issue from both positive and negative impacts. In his piece on the unintended consequences he argues for a much needed debate, "High stakes tests: we do not know how to live with them; we cannot seem to live without them" (p. 26).

However, despite these calls for debate and arguments to limit their use, standardized testing, as the primary means of assessing students and holding schools accountable, continues to prevail and hold center-stage (Au, 2007; Honig, 2006; Weaver-Hightower, 2008). The latest version of Federal Policy called Race to the Top is cast as an opportunity to gain waivers from No Child Left Behind requirements. This policy, however, continues and expands the use of standardized test scores in assessment and judging schools' effectiveness. The policy calls for linking standardized test scores to not only student and school performance, but also to teacher and principal performance (McNeil \& Klein, 2011).

Continuing the argument against this narrow focus on testing as the gold standard for assessment and accountability is important for educators and researchers. However, equally critical is the need to simultaneously create and advocate for what Sirotnik (2002) calls "socially responsible" systems of assessment and accountability built upon current principles of learning. Sirotnik (2002) describes assessment as the gathering of data and accountability as what is done with the data. Currently, data are narrowly defined as test scores. Assessment is seen as gathering those data (test scores). Accountability is then seen as posting of those scores for the public and others to use in making judgments and educational decisions about the value of school programs and school personnel. Instead of this scenario, Sirotnik (2002) argues for the development of a "socially responsible" assessment and accountability systems. Such systems would utilize multiple indicators (quantitative and qualitative) of student performance "that are sensitive to the needs of each individual and to the purposes and complexities of schooling, including contextual conditions..." (p. 666). The system would incorporate many forms of performance assessment and embrace democratic participation of students, educators, and community members. It would also be consistent with current knowledge about child development and learning.
Eva Baker (2007), in her AERA Presidential Address, entitled "The End(s) of Testing," extends Sirotnik's (2002) argument. She advocates for the use of a variety of measures and means for designing assessment processes. Like Sirotnik (2002), she raised the concern of the "...evidential disconnect between test design and learning research..." (p. 310). The disconnection between learning theory and assessment practices is a common concern throughout the research (Bransford et al., 2000; Broadfoot et al., 2004; Pelligrino et al., 2001). As Baker (2007) concludes:

...unless we find something tangible, beyond a test score, that engages and fulfills students and teachers, education will continue to shrink and shrivel, and with it our chances to balance our hopes and aspirations with the comfort of accomplished learners" (p. 315).

Baker (2007) calls for attention to new means of assessment that focus on current learning theory. This call is consistent throughout the literature on learning and assessment (Bransford, Brown, \& Cocking, 2000; Broadfoot and Black., 2004; Pelligrino, Chudowsky, \& Glaser, 2001). Herein, lies both an opportunity and a challenge for educational leaders - to seize the intense focus on assessment and accountability and reframe the views and practices of assessment and accountability. And, in the process, also possibly re-frame our schools.

Carl Glickman and Derrick Alridge (2001) present an idea that may advance Sirotnik's call for responsible accountability and Baker's and others' pleas for multiple means of assessment that grow from current literature on learning. Their idea, simply stated, is "going public" with student learning - making learning much more transparent to students, educators, families, and community members, in other words, to the public. Democratic ideas are not often reflected or encouraged in educational assessment and accountability methods. Perhaps, recognizing and reconciling this omission may move schools and their assessment and accountability practices toward some of the goals called for by Sirotnik, Baker and others.

Developing alternative assessment and accountability processes may also provide a necessary forum for the examination of long-held taken for granted "modernist assumptions" about schooling and learning. These conventional ideas are embedded in the mental schemata of 
those who make up the school and its community. By its very nature, public education in a democracy is a political undertaking involving the polis (educators, politicians, parents, community members). The key to reforming schools may lie in our ability to simultaneously reform the conceptions of schooling of the polis's members, while also reforming schools. Creating experiences that bring educators and citizens together in exploring and debating understandings (mental schemata) about schooling may hold promise in advancing school reforms (Heckman \& Montera, 2009). Assessment processes can provide a means to 'go public' with children's learning and provide a forum for public examination of our "modernist assumptions."

"Going public" moves assessment and accountability away from national policymakers and corporate interests to the interests of individual students, schools, and communities. Three aspects of 'going public' frame this work. First, 'going public' means a focus on local assessment tied to classroom and school programs. 'Going public' challenges educators to move assessment and accountability away from annual reports presented in newspapers to ongoing and in-depth descriptions and discussions of student learning at the school site with many constituents. In section I, Going Public: Focus on Local Assessments, the background and development of the process undertaken at the school will be presented.

Second, 'going public' means engaging in interactions with stakeholders around and about students' learning. It brings together stakeholders in school and classroom settings to democratically account for and assess student learning and school programs. In section II, Gong Public: Engaging Stakeholders, a narrative of one assessment experience is presented. This narrative was constructed from empirical data gathered during the events and processes of one assessment activity. Engaging in the narrative taps into the ability to "envision alternatives-to conceive of other ways of being, of acting, of striving" (Gergen as cited in Bruner, 1990, p. 109-110). This narrative may be a way to tap into imagination and provide an opportunity to bring others vicariously into an alternative school culture to expose and examine ideas about learning and assessment.

Third, and most importantly as a result of engagement, 'going public' means democratically developing common conceptions and values for learning within a school and community. Opportunities are created to collectively ex- amine taken-for-granted ideas (mental schemata) about learning in order to reform conceptions guiding a school's program and practices. In section III, Going Public: Developing Common Conceptions, seven key ideas emerging from the literature on learning and assessment are used to discuss the narrative and consider how these ideas influence the development of an alternative assessment process and common conceptions about learning.

This article presents an empirical case study of one school's efforts to develop an alternative assessment process that reconciled the external uses of assessment with its central role as a tool in the teaching and learning process by "going public." What is presented is an "instrumental case study." It is an instrumental case study that has a clear purpose to "accomplish something" (Stake, 1995, p. 3). The principal and the teachers set out to develop an alternative assessment process to counter the growing reliance on standardized testing. This case study grew from "lived experience" (van Manen, 1990, p. 9) wherein the researcher (the principal) had the opportunity to "retrospectively" (p. 10) understand and identify the implications of the experience. Empirical evidence was gathered and analyzed in describing this work and in constructing the narrative presented here. More detail regarding the methodology of this research is presented at the conclusion of the article. Importantly, the development of this alternative assessment process called on the imagination of those who were a part of this project and their willingness to take a risk. Understanding this alternative will happen as the reader imagines being a part of this creation.

\section{Going Public: Focus on Local Assessment}

Rock City School, in California, was established as a K-8 "alternative" school in the fall of 1973 within a public school district. The genesis for the school came from a group of community activists seeking a school where non-authoritarian, non-competitive, non-sexist methods would be emphasized.

Over the decades, however, the school lost its way as the context surrounding it changed. When many in the district wanted the school closed, the superintendent saw the school as an opportunity. He challenged the staff and me, as the new principal, to create a program built upon the latest and strongest research on learning and child development. In designing the school's instructional program, the teachers and I also had to address the issue of 
assessment and accountability. Traditional approaches to assessment would not match the dynamics we were promoting in the learning process.

With a great deal of discussion, debate, and exploration of the literature on cognition, learning, and assessment, we set out to create assessment processes that would match the dynamics we were promoting in the learning process. To guide in the development of assessment practices and activities, we first identified our overarching goal for assessment. Recognizing that assessment serves several purposes, we then determined our primary purposes of assessment. Finally, we developed guiding principles that would be used in creating the activities that would eventually make up the assessment process.

\section{Overarching Goal}

In establishing the overarching goal, it was important to state the core objective of the assessment process, as well as what was not going to be the focus. The following overarching goal was established:

Our goal in assessment is to understand and know the complexity of each child's development rather than to compare children with each other. If we are to uphold the tenet that each child is unique, then it is imperative that this belief be reflected in our practices of assessment, as well as instruction. (Rock City School, 2013, p. 12).

At the heart of this goal was focusing the assessment processes on seeking insights and learning about students' knowledge and development. It brought attention to the children's growth and knowledge, rather than on their ranking or on comparisons among them. This goal put the emphasis in the process squarely on the individual child's development.

\section{Primary Purposes}

Establishment of the overarching goal was followed by decisions identifying the primary purposes for the assessment process. Assessment serves many purposes and audiences. Of these purposes, the teachers and I agreed upon which of these would be the focus of the work. The purposes identified were:

\section{Purposes of Student Assessment}

- To increase student, teacher, and parent awareness of a child's strengths and growth.

- To gain insight into child's thinking and understanding.

- To assist children's authentic development of selfknowledge.

- To inform teachers about the need for programmatic/ instructional changes or activities.

- To increase students' and teachers' thoughtfulness about their work.

- To communicate to children and families expectations and standards. (School Handbook, p. 12).

Each of these purposes was grounded in the literature on learning and assessment. We wanted to identify a child's strengths and build on their existing knowledge (Bransford et al., 2000; Gonzales, Andrade, Civil, \& Moll, 2001; Vygotsky, 1978). By gaining insight into and understanding a child's thinking, we would better be able to adjust instruction and provide support as needed (Langer, 1997). The development of one's self-knowledge has long been identified as critical to one's success (Pintrich, 2002). The information would be helpful in developing the school program and instruction. Finally, helping children and families understand the school's program and its contribution to learning was vital in addressing the accountability aspect of our program.

In their review of the literature on assessment, Pelligrino et al. (2001) identified three main purposes of assessment in schools. These are to:

a. assist learning

b. assess individual achievement

c. and provide information upon which to evaluate programs (p. 37-40)

The purposes developed by the school staff are consistent with these three main purposes identified in the literature. Table 1 compares the school's purposes with these three main purposes of assessment found in the literature.

This comparison and connection to the research literature on assessment helped guide our decisions regarding the development of the assessment process. It also ensured that we were meeting the multiple purposes embedded in assessment practices. 
Table 1

Comparison of School Purposes with Research Literature

\begin{tabular}{|c|c|}
\hline $\begin{array}{l}\text { Purposes of Student Assessment } \\
\text { (Rock City School) }\end{array}$ & $\begin{array}{l}\text { Common Purposes } \\
\text { (Pelligrino, et. al., 2001) }\end{array}$ \\
\hline $\begin{array}{l}\text { To increase student, teacher, and parent awareness of a } \\
\text { child's strengths and growth }\end{array}$ & b. assess individual achievement \\
\hline To gain insight into child's thinking and understanding & b. assess individual achievement \\
\hline To assist children's authentic development of self-knowledge & $\begin{array}{l}\text { a. assist learning } \\
\text { b. assess individual achievement }\end{array}$ \\
\hline $\begin{array}{l}\text { To inform teachers about the need for programmatic/instruc- } \\
\text { tional changes or activities }\end{array}$ & $\begin{array}{l}\text { a. assist learning } \\
\text { c. evaluate programs }\end{array}$ \\
\hline $\begin{array}{l}\text { To increase students' and teachers' thoughtfulness about } \\
\text { their work }\end{array}$ & $\begin{array}{l}\text { a. assist learning } \\
\text { b. assess individual achievement } \\
\text { c. evaluate programs }\end{array}$ \\
\hline $\begin{array}{l}\text { To communicate to children and families expectations and } \\
\text { standards }\end{array}$ & c. evaluate programs \\
\hline
\end{tabular}

\section{Guiding Principles}

From these purposes, guiding principles were developed to direct the design of the school's assessment process and activities. Again, the research on learning was used in deciding on these principles. The "Guiding Principles" established by the staff are identified below.

- The assessment process/activity will be child-centered. The focus will not be on the outside knowledge given to a child, but what the child is coming to know, understand, and do.

- The assessment process/activity will be interactive in nature. It will involve discussion, conversations, and writing with students, teachers, and parents.

- There will consistently be an opportunity for children's self-assessment. The teacher will help guide this process, but the child will be an active participant in the assessment activity rather than a passive receiver of an outside evaluation.

- The assessment process/activity will focus on a child's assets and growth.

- As much as possible the assessment process will be contextualized, in that it will take place within the process of learning-in-action rather than solely [focusing] on a final product.
- The assessment process/activity will be on-going throughout the child's time at the school. This process will be qualitative and will involve both formal and informal assessment opportunities.

- Assessment will be linked to the goals/standards identified in the [school] handbook.

These guiding principles will be discussed in-depth in the third section entitled Going Public: Developing Common Conceptions.

\section{Formal Assessment Process}

From the guiding principles, a formal assessment process was developed. The process and activities that made up the formal assessment process spanned the school year, with a Fall Family Conference at the beginning of the school year, a Mid-year Assessment Activity, and a final end of the year Spring Narrative. Each of these is described below.

\section{Fall Family Conferences}

Prior to the Fall Family Conference, students planned for the event by reviewing their work from the previous year and considering areas of development and future growth they would like discussed with their teacher and 
family members during the conference. Students took an active role in describing and explaining their progress and plans for the school year. In planning for the conference, students reflected on previous work and growth. They developed goals for the year that would be used by them, parents and teachers throughout the year in assessing their progress. A student's teacher moderated each individual Fall Family Conference, however, the student was the focus and the critical participant in the event.

\section{Mid-year Assessment Activity}

The Mid-year Assessment Activity varied as we tried out numerous means to integrate learning, assessment, and school-family-community interactions. It was our hope that this effort to strengthen our assessment process at the school would be intimately connected to our dayto-day work with children. We also hoped it would reveal to students, parents, teachers, and others outside of the school what children were learning in ways that we felt traditional methods (test scores and report cards) could not reveal. The creative and imaginative activities developed continued to evolve as we learned more and more about ways to enhance our assessment practices and develop student and community learning. An illustration of one of these events is presented in the next section.

\section{Spring Narrative}

Each spring, prior to the end of the school year, families received a "comprehensive narrative assessment" (School Handbook, p. 15) of each child's development. This narrative was tied to the school's program and identified goals. It was also tied to students' identified goals from the Fall Family Conferences. This was the student's summative assessment of their work and development during the school year. Teachers developed each narrative from data gathered throughout the school year on the child's performance. Students contributed to the narrative with their own self-assessment. These narratives were provided to families prior to the end of the school year to enable further discussion of a child's growth. They were also used in the Fall Family Conferences the following school year. These annual narratives captured the child's development throughout their time at the school.

We worked to create an assessment process that embraced the multitude of factors that influence children's learning and engendered discussion and learning about this complexity with all stakeholders. The assessment process developed incorporated both formative and summative methods. Formative assessment occurred during the learning processes that led up to the completion of students' projects. Much of what was presented during the Fall Family Conferences and the Mid Year Assessment Activities was formative in nature as will be illustrated in the next section. Summative assessment did happen during the school year upon the completion of a project or assignment. However, the formal summative assessment occurred with the Spring Narrative.

In the next section, a narrative of one of the Mid-year Assessment Activities is presented to illustrate how some of the complexity of the learning and assessment process was revealed and utilized to build understandings of the learners and of the learning process within the school. This example also illustrates the kind of discussion that emerged throughout the assessment process.

\section{Going Public: Engaging Stakeholders}

Imagine you are invited to your neighborhood school for an afternoon to talk with children about their work. You don't have any children in the school, but, as a neighbor, you have become acquainted with the principal because you have raised issues about the high decibels of sound emanating from the school playground-sometimes overpowering your own music. You have also talked to the city police about the traffic congestion before and after school. Yes, you are an involved citizen and, perhaps, not exactly thrilled with this school in your front yard. The principal invited you to this event suggesting that you were quite informed about what happened outside of the school and thought it might also be important for you to become acquainted with what goes on inside of the school.

You enter a large classroom filled with 7 to 10 yearolds, their family members, and teachers. Everyone gradually takes a seat. Several teachers take turns in stating the purpose of the gathering and the process. They encourage everyone to seek and share information about students' learning and thinking.

You are then directed to your assigned group made up of 3 children, their guests (parents and family members), and a teacher. The children know this is their time to talk about and share their work with others. Prior to the meeting, they have been given the opportunity during 
their school day to decide what they want to share and talk about - many of the projects chosen are in-process, not yet completed work.

A nine-year-old boy starts by sharing a writing project he has been working on. He talks about where he got his ideas, reads a part of the story to the group and then explains where he thinks the story is going next. An adult asks what he does when he can't think of an idea. The boy talks about his own process of dealing with writer's block, which includes "taking a break" or "visiting with his friends." Another adult asks about a finished product. "Do you ever finish a story? What do you do to finalize it?"

The boy talks about conferencing with others and then says, "I follows the steps."

"What steps?" another adult asks.

"The ones on the chart!" the boy responds as he jumps up, runs across the room, and takes a hand-made chart off the wall, which the children created to assist them in their writing process. He returns to the group and quickly begins to explain each step on the chart. The teacher notes his explanation and how he is using this tool to develop his writing.

His mom, sitting next to you, seems surprised by her son's expression and leans over to you and says, "I've never heard him talk like this. I had no idea he was working on this in school!"

The conversation about his writing ends with him sharing where the story might go next.

The next student brings a diorama to the table she has created to represent a scene from a book she is reading. The construction is clearly the work of her 7 year-old hands. After explaining the story and her scene, her teacher who knows reading has not been a favorite activity for this student asks her a question about her reading, "How did you choose this book?" The child shares why she has chosen the book and continues to read this book.

As the child answers the teacher, other questions come from the adults in the group: "What do you think about as you read?" "What other things have you read?" "What is the best part of reading?" All of the questions were seeking the child's considerations about her own reading style.

Then, a parent, who knows that the child struggles with reading and has previously questioned the school's reading program, asks, "Do you ever get to a word you can't read?"
"Oh sure," the girl responds without hesitating.

"What do you do?" asks the adult." How do you figure it out?"

Again, without hesitating, the child responds, "I skip it!"

There is a moment of silence, a few adults exchange glances. The teacher does not respond right away and another child jumps in, "Sometimes you can get help, but it slows you down."

Two adults, including the one who asked the question, lean forward into the group. One says, "Aren't you worried about missing a word?"

"If I keep seeing it, I might ask for help," the girl responds as the teacher makes a note to explore this idea further with the child.

The third child, who has been enamored with ships for the past year, has chosen to talk about his recent discoveries about the types of ships used in World War I. He presents and explains, in detail, several of his drawings. His attachment to and interest in the topic are evident.

"What do you think you are learning by studying and drawing these ships?" asks an adult.

"Well, I like to see the parts that are on them and how they work," he then pauses briefly, "but my parents said I have to choose something else next time."

His parent quickly responds. "We just want you to learn about other things." The teacher notes the interaction.

After the initial presentations, the teacher asks if there are other questions for the students. As the conversation goes on, the children's participation increases. They begin to ask each other questions and jump in when it looks like a peer needs help.

Next, everyone returns to the large group to share their thoughts about what they have learned and questions they still have. Parents voice surprise by the interactions and thoughts the children expressed. Others still wonder if their child is progressing, as he should. You, along with the other adults, are given a survey to capture your thoughts, questions, and concerns. You are asked to return it to the school the following week.

This assessment event existed within an on-going process. In the days following the event, teachers met with the children to ask them what they thought, how it felt, what they discovered and might do differently. They also followed up on information that arose during the as- 
sessment gathering meeting with a student or having an informal conversation with a parent.

During the group debriefing with students, students expressed nervousness, pride, and discovery about what their fellow students were working on.

"I had no idea Jamie was writing a mystery, I want to read it!"

"It felt weird like they were judging me, but when I used to get my report card, I didn't think about it!"

"Two parents made me feel like I hadn't done my research and survey according to logical reasoning and made me feel like I needed to start over.... My insight was that I get too carried away sometime and I forget what is logical."

Teachers also met to share their learning about the children and the process. Their notes were reviewed and activities modified. Small actions were taken, such as following-up with a child or parent or making a programmatic or instructional change.

The surveys that were given to the parents and community members were carefully reviewed to learn about parents and community views, and their concerns and questions. This information was used to create and build other experiences in other venues, from developing articles for the weekly school newsletter to providing items for parent forums or community education nights.

Finally, a report about the event was written by the school staff and sent to the school community, district office, and school board.

\section{Going Public: Developing Common Conceptions}

This section explores both the educational and public nature of assessment. In this first section, The Educational Nature of Assessment, the previous narrative is analyzed through the lenses of seven key ideas from the literature on learning, cognition, and assessment. These seven ideas are critical aspects to consider in developing assessment processes linked to student learning. Here each idea is elaborated fully and then connected back to the school's developing assessment process and guiding principles. The second section, The Public Nature of Assessment, outlines how this process of assessing student learning may also provide a democratic forum for all stakeholders to assess and reconsider their assumptions and understandings of student learning and schooling practices in order to promote school reform.

\section{The Educational Nature of Assessment}

Prior to developing the alternative assessment process, the school staff identified several Guiding Principles to be used designing of the activities that made up the school's assessment process. These Guiding Principles correspond to seven key ideas that emerged from the literature on learning and assessment.

The seven key ideas identify the importance of:

1. Eliciting explanations and making thinking visible.

2. Utilizing communities of learners.

3. Developing metacognition and self-assessment.

4. Recognition of existing knowledge.

5. Attending to process and context.

6. Embracing complexity.

7. Linking learning and assessment.

Examples from the assessment events described earlier illustrate a relationship between these ideas and the enactment of the school's assessment principles. Table 2 illustrates the relationships between these key ideas from the literature and the guiding principles developed by the school staff.

The key ideas and the assessment process are discussed in each section below with supporting literature. As with so many aspects of learning and assessment, the key ideas are interrelated and overlapping.

\section{Key Idea 1}

Eliciting and Making Thinking Visible

The creation of opportunities for students to express, reveal, and make their thinking visible has been identified as critical in the learning and assessment process. Eliciting these expressions enables adults to understand students' sense-making and better assist them in furthering children's development. Also, by drawing out the learner's thinking, the learner gains insights about his/her own understanding, which is often hidden from them (Black \& William, 1998, Bransford et al.; Pelligrino et al.; Furtak et al., 2008).

The first guiding principle focused on students' thinking and knowledge. Children's thinking was made visible throughout the process and in multiple ways and settings in students' classrooms and assessment events. Initially, students were asked to reflect on their classroom work during the time leading up to the assessment event. They then prepared what they would like to share with others during the assessment activities. This process of reflection 
Table 2

Research Literature's Key Ideas in Relation to the School's Guiding Principles

Key Ideas Identified from the Literature

1. Eliciting and making thinking visible

2. Utilizing communities of learners

3. Developing metacognition and self-assessment

4. Recognition of existing knowledge

5. Attending to process and context

6. Embracing complexity

7. Linking Learning and Assessment
Rock City School's Guiding Principles

The assessment process/activity will be child-centered. The focus will not be on the outside knowledge given to a child, but what the child is coming to know, understand, and do.

The assessment process/activity will be interactive in nature. It will involve discussion, conversations, and writing with students, teachers, and parents.

There will consistently be an opportunity for children's selfassessment. The teacher will help guide this process, but the child will be an active participant in the assessment activity rather than a passive receiver of an outside evaluation.

The assessment process/activity will focus on a child's assets and growth.

As much as possible the assessment process will be contextualized, in that it will take place within the process of learningin-action rather than solely focusing on a final product.

The assessment process/activity will be on-going throughout the child's time at the school. This process will be qualitative and will involve both formal and informal assessment opportunities.

Assessment will be linked to the goals/standards identified in the school handbook. occurred during the school day with teachers and peers. During the assessment event, students discussed their work and responded to questions about that work from their audience made up of family and community members. For example, the student writer revealed his writing process and use of the writing 'chart.' The student reader expressed her thoughts and strategies for reading. The ship historian spontaneously voiced something on his mind that may be troubling him.

Finally, in their debriefing groups, the next school day, students were again asked about what they were thinking in relationship to the process and the discoveries they made about their thinking during the assessment event. As children spontaneously responded to questions in these debriefing discussions, educators gained insights about each child's views and understandings. Subse- quently, in follow-up classroom projects and activities, they used those insights to further expand the children's knowledge and encourage their growth in these areas.

This idea of making thinking visible in assessment and learning activities was also present for the adults as they experienced these assessment activities and discussed them with other adults prior to and after the events. This process helped reveal adults' conceptions and views of the assessment and learning processes at the school. These revelations provided an opportunity for them to examine their mental schemata with each other.

\section{Key Idea 2}

Utilizing Communities of Learners

The research literature conveys the importance of learners' interactions with peers, teachers, and other in- 
terested adults in making arguments, elaborating ideas, considering alternative points of views. Adults and children acquire and restructure their knowledge through discourse and interaction with others (Brown \& Palincsar, 1989; Cobb, 1998; Furtak et al., 2008; Pelligrino et al., 2001). Vygotsky (1978) stated, “....interactions provide a source of development" (p. 90). He argued for the recognition of the social nature of learning and the "process by which children grow into the intellectual life of those around them" (p. 88). This social nature of learning happens as each person reveals their thinking to others, thus, assisting themselves and others in developing their ideas and thoughts.

The second guiding principle addressed the importance of social interaction in the assessment process. A great deal of interaction happened during and after these assessment events, fostering the development of a community of learners among teachers, students, family and community members. For example, during class planning for each assessment event, students consulted with each other about what they planned to share in their groups. They frequently wrote about their plan and discussed it with their peers and teachers. During the school day, students also had multiple opportunities to collaborate with each other on a class project or assignments such as their writing projects and group science projects.

Numerous forums provided opportunities for the adults to also reveal and examine their own conceptions of schooling and learning. Prior to and after many of these assessment events, teachers came together and examined and discussed the data they had been gathering about children's work and the children's developing learning and thinking. For example, in the assessment event illustrated here, a parent was surprised by her son's work and his explanation of his writing. She had not experienced him doing this kind of work and talking about it as he had done during the assessment event. Later, she and the child's teacher considered ways that she could possibly extend the conversation (and learning for both of them) at home. Several parents also had opportunities to reconsider their views of what was involved in reading. What were the consequences of skipping a word? Is reading more than knowing every word? This developed into a conversation beyond the assessment event that continued and influenced understanding of the act of reading and the school's reading program. In other situations, family members met with teachers following an explora- tion in the classroom. They discussed their observations and questions about what they experienced in interacting with and observing their children in this process.

Surveys given to the adults following an event, sought the adults' views of the alternative assessment process and activities regarding what they learned and what information they felt was missing in the process. Faculty used these data in planning other events and developed ways to highlight and address questions arising about the assessment process or school's program. These ideas were addressed in presentations at a PTA or sitecouncil meeting, and in a follow-up story in the school's weekly newsletter. Information from the surveys was also used in writing a report of the event and sending it to the district office. The sense of community was extended beyond those directly involved in the school by inviting community members from the neighborhood to participate in the event and to keeping members of the district administration and school board informed of the assessment activities.

\section{Key Idea 3}

\section{Developing Metacognition and Self-Assessment}

Throughout the learning, cognition, and assessment literature researchers note the importance of developing and encouraging metacognition and opportunities for self-assessment (Bransford et al., 2000; Pelligrino et al., 2001). Urging learners to explain and evaluate their thinking and reasoning greatly assists in the development of a learner's understanding and expertise (Bereiter \& Scardamalia, 1989). Ericsson and Simon call this a "think aloud method" (as cited in Shavelson et al., 2003, p. 15). In addition, this activity of thinking aloud about one's thinking and assessing one's own work assists teachers in knowing first-hand how students are making sense of concepts so the educators can improve their instruction and assist in student learning (Bereiter and Scardamalia, 1989).

The third guiding principle highlights the critical importance of involving students in metacognitive and self-assessment activities. In preparing for the assessment events, children were asked to reflect on their daily classroom work and progress. Students chose what they wanted to present at the event. During the assessment event, students were asked to share their thinking and strategies for figuring out what to write about or how to read. They also explained what they knew, how they knew 
it, and why they had chosen a topic or plan of action in the project they were presenting. Together these kinds of activities assisted students and the adults in recognizing and understanding students' thinking, what may be influencing students' understandings, and how the students saw their development. For example, one student shared how the questions adults asked her during the assessment activity made her rethink her strategy about how she had conducted what she thought was a "logical" research project.

This idea of student self-assessment was repeatedly built into the school's on-going assessment activities with students' central involvement in their self-assessment during the Fall Family Conferences and culminating with their contributions to their individual Spring Narrative at the end of the school year. As one child explained, "It's good to share what you know, not what the teacher knows about you." How the child sees this "as good" was part of the continued exploration. Together, these interactions engendered metacognition and self-assessment.

\section{Key Idea 4}

\section{Recognition of Existing Knowledge}

All humans construct knowledge, mental schemata, of their world. They use these schemata in making sense of the world. This existing knowledge, often termed prior knowledge, serves as a foundation on which individuals build new knowledge. Just as this prior knowledge assists in learning, it can also hinder interpretation and development of new knowledge. This aspect of learning leads to the importance of educators and children identifying, understanding, and embracing a student's existing knowledge, their views of the world and the ways that they think about them (Bransford et al., 2000; Gonzales et al., 2005; Vygotsky, 1978).

The fourth guiding principle places the focus on the identification of a child's assets and growth. We created opportunities for children to be expressive and make choices about their learning and assessment. In that process, educators discovered a great deal about students' existing knowledge and how students use that knowledge to made sense of the world. For example, a child explicitly expressed his understanding of a writing tool (his chart), another shared her increasing interest in reading, and another child expressed what he knew about ships, how he built his knowledge about ships overtime, and a barrier he faced with his parents' efforts to re-direct this interest instead of following his interests.

Each of these examples provided expanded conversations about students' understanding and learning, as well as the adults' views of that learning and the school's program. Embedded in the process were multiple opportunities to explore, to question, and to imagine alternatives.

\section{Key Idea 5}

Attending to Process and Context

Learning is not an event, but rather a process of building and creating knowledge and expertise (Sternberg, 1997). In the learning process, as previously presented, learners actively construct knowledge. The context in which this knowledge is constructed can enhance the learning or interfere with that knowledge development (Bransford et al., 2000; Edelson, Gordon, Douglas, \& Pea, 1999). Context has been described as the variety of forms of engagement and situations in which an individual participates (Pelligrino et. al). These contexts - the one that exists within the school/classroom and the one with which the learner is familiar in his home or community influence sense-making (Spillane et al., 2006). Contexts provide the learner with cultural artifacts, tools, and language that "mediate" their learning and cognitive development (Wertsch, 1998).

The fifth guiding principle recognizes the process of learning and the influence of context on that learning. To acknowledge learning as a process rather than event, multiple settings were established to provide students, educators, family and community members with opportunities to assess student learning. Mid-year activities, as the one described here, often focused on student work in process. This allowed the demonstration of a student's ongoing development rather than focusing on the quality of a final product. It also allowed students to exhibit their distributed knowledge (Gonzales, Moll, \& Amanti, 2001) in the assessment process. Students responded to questions such as, how they use resources, what meaning do tools have for them, what knowledge and other resources do they draw on in making predictions or plans for next steps, and what barriers do they encounter.

Family and community members were invited to become part of the learning context of the school in numerous ways. The events in which they participated influenced their sense-making of the school's program and 
a child's learning in this alternative environment. As one parent wrote, "the alternative assessment process gives students and their families authentic information about progress toward educational goals." Others identified how it assisted in their understanding of the school program. And others voiced concerns about the lack of information gained on the ranking or specific leveling of children. They felt this was needed to help them know 'where their child is' in comparison to others. These contexts led to other contexts for discussing adults' comments and questions.

\section{Key Idea 6}

\section{Embracing Complexity}

Rapid economic, social, and technological change characterizes the world today. New knowledge and information are increasing at rates not experienced during the previous century. The world students will navigate in the future is largely unknown today (Friedman, 2005). Capturing and promoting this unpredictability and complexity about an ever-changing world requires a multi-faceted assessment process, which is why researchers have argued for developing multiple means of assessing student knowledge and learning (Baker, 2007; Black \& William, 1998; Pelligrino et al., 2001; Shepard, 2000).

Many factors influence the learning and assessment processes (Bransford et al., 2000). Assessment of an individual's knowledge at any one point in time is only an approximation of that knowledge (Pelligrino et al., 2001). Creating multiple opportunities and settings for children to exhibit and develop knowledge over time allowed us to embrace this complexity and the long-term nature of learning. These assessment opportunities also promoted students learning by providing a clearer picture of what and how students thought. They also revealed a closer approximation of the child's knowledge development than a one-time summative assessment activity.

The sixth guiding principle establishes the importance of embracing complexity by creating an on-going and multi-faceted assessment process. In the assessment events discussed here, respect for children's ideas was center-stage. Children's responses and thinking were explored rather than evaluated. These events contributed to adults' understanding of the complexity of the learning process from highlighting children's own sense of efficacy in building skills and knowledge to their interests in projects they chose to explore. The open nature of the activi- ties allowed for the complexity and the many interesting issues in learning and schooling to be revealed and explored in a community of learners rather than controlled and directed. By embracing the complexity and the developmental nature of the work, adults examined different perspectives. They learned from each other. The educators made adjustments in their programs and the parents began to better understand how this alternative program helped their children learn by building on the current research knowledge of learning to change the school's practices and children's experiences.

\section{Key Idea 7}

\section{Linking Learning and Assessment}

Linking learning and assessment seem obvious. Yet, too often, assessment is viewed as an end rather than part of the process of learning (Baker, 2007). Pelligrino and his colleagues concluded learning is an iterative and not a linear process (Pelligrino et al., 2001). Bransford et al. (2000) identified assessment as one of the critical features of effective learning environments, arguing that learning environments must be assessment-centered, as well as knowledge-centered, learner-centered, and communitycentered. Throughout the research literature, the plea is made to build assessment on a model of learning and cognition-a connection that is too often missing (Baker, 2007; Pelligrino et al., 2001; Shepard, 2000).

Pelligrino et al. state, "A model of cognition and learning should serve as the cornerstone of the assessment design process" (2001, p. 3). Therefore, it remains critical that educators strive to link learning with assessment and to conduct assessment activities within the same conditions and environments created in the classroom to encourage student learning. This idea is pervasive throughout this analysis.

The final guiding principle developed by the faculty established the importance of linking learning goals and assessment processes as an element of the assessment design. The framing of this last guiding principle served two purposes. First-politically - to send clear messages to the larger community that the school's goals/standards would serve as the criteria upon which the assessment process would be built. Second-educationally-while this guiding principle largely identified the connection of the assessment process to school goals/standards, in practice it served as a reminder for the educators as they 
designed an assessment process that grew out of the learning program they established. Designing assessment practices that were consistent with the instructional program was the impetus for this alternative assessment work. As evidenced in this analysis, the ideas presented in the learning and assessment research literature did serve as a foundation for the development of the alternative assessment activities discussed in this article.

\section{The Public Nature of Assessment}

At the beginning of a comprehensive report on educational assessment entitled, Knowing What Students Know, the editors state:

The central problem addressed by this report is that most widely used assessments of academic achievement are based on highly restrictive beliefs about learning and competence not fully keeping with current knowledge about human cognition and learning.

(Pelligrino et al., 2001, p. 2)

The process of 'Going Public' shows how this one school attempted to close the gap between its assessment practices and the insights gained from "current knowledge about human cognition and learning." In the process, "highly restrictive beliefs about learning" (p. 2) and schooling were revealed and explored.

Radical change in the conduct of student assessment is deeply connected to the conduct of school (Baker, 2007; Bransford et al., 2000; Sirotnik, 2002; Pelligrino et al., 2001; Popham, 2001; Shavelson et al., 2003; Shepard, 2000). Yet, the reform literature tells us that when reformers urge a shift in schooling practices-there is often resistance from those within and outside of the school (Tyack \& Cuban, 1995). This resistance often arises out of a lack of understanding about a reform effort. Spillane and his colleagues (2006) attribute this lack of comprehension or embrace of the new to one's existing mental schemata. When new knowledge does not match the old knowledge there is often conflict with and rejection of the new policies and practices.

We knew we could not merely give up testing without a public and community outcry. Instead, in this assessment process, we replaced the 'giving up' with 'going public.' 'Going public' offers three guides for educational leaders in addressing alternative assessment and school reform. First, focus on local assessment. Work with school colleagues to develop a local assessment process linking learning and assessment. Second, engage stakeholders. Increase the transparency of your work. Invite stakeholders to interact with students and hear directly from them about their ideas, understandings, and learning. In addition, create opportunities for stakeholders to debrief, debate, and explore their understandings and questions. Third, in doing this, communities of learners can be established to develop common conceptions and understandings about the learning and assessment process. Ironically, the principles and key ideas presented in section III, Going Public: Developing Common Conceptions, regarding assessment are also those that educational leaders should consider and incorporate in transforming schooling practices. Keeping these seven key ideas in mind will provide guidance in transforming our schools. As educational leaders, it is important to elicit and make students' and adults' thinking visible within a community of learners. This process engenders metacognition and reflection on the part of the students' and adults. It allows others in the community to recognize each other's existing knowledge and understandings. This should be done overtime within the context of children's learning in multiple venues. Educational reform and learning are complex processes that are symbiotically linked. Embracing these principles and key ideas will engender an environment of learning for children and adults, which will provide openness for educational reform away from our "modernist assumptions" (Broadfoot \& Black, 2004, p. 20) and "highly restrictive beliefs" (Pelligrino et al., 2001, p. 2). In order to shift our assessment and accountability practices, we will need to create opportunities such as these to simultaneously reveal, explore, and shift the mental models of the polis (Bransford \& Black, 2009; Broadfoot et al., 2004; Heckman \& Montera, 2009; Pelligrino et al., 2001).

\section{Conclusion}

Assessment has three major purposes: to assist learning, to assess individual achievement, and to provide information for program evaluation (Pelligrino et al., 2001). Some have argued that an assessment activity cannot adequately serve more than one of these three purposes (Pelligrino et al., 2001). Thus, it was important to develop an assessment process incorporating multiple means and 
opportunities to embrace rather than limit the multiple purposes of assessment. Doing this engaged the public in the assessment process. These purposes bring attention to the role that "responsible accountability" (Sirotnik, 2002) can play in advancing more effective schooling practices. As Sirotnik concludes, such a system "...accounts in ways that do not stress on-demand, high stakes tests... but that focus instead on a broader array of indicators and resource-rich educational environments characterized by all the good conditions and practices known to facilitate better teaching and learning" (p. 670). Engaging in local assessments and local discussions about student learning does offer "a broader array of indicators" and alternatives to the commonly accepted focus on test scores. Understanding the educational and public nature of assessment provides insight and opportunity for educational leaders to influence public conceptions of the learner and the learning process, and, in turn, possibly transform our schools and schooling practices.

In his address to the John Dewey Society in 1975, Lawrence Cremin argued that, "The proper education of the public and indeed the proper creation of publics will not go forward in our society until we undertake anew a great public dialogue about education" (p. 11). The ideas presented here on alternative assessment engender that dialogue, which may be more needed today, than in 1975.

"Going public" (Glickman \& Aldridge, 2001) offers a way to think about the development of local assessment that is socially responsible (Sirotnik, 2002) and utilizes multiple means of assessment (Baker, 2007). It also incorporates features of assessment that have been widely called for by researchers - features that are rarely experienced in current school settings, despite their well-established value (Pelligrino et al., 2001). Lastly, it provides an opportunity for all stakeholders to rethink their ideas of schooling and, perhaps, reframe their schemata guiding their views about schooling (Heckman \& Montera, 2009; Spillane et al., 2006) by eliciting and making transparent everyone's thoughts and actions. Inviting the public to interact with and hear directly from learners increases awareness of the insightful thinking of children in ways not evident in traditional assessments. Questions raised in the process can then serve as invitations to learn and create together, to imagine and co-construct a new school environment democratically.
The evidence and discussion provided here is a call for many more efforts to imagine what we do not yet know while inventing new means of capturing and promoting students' learning and examining adults' understanding about that learning. Creating opportunities throughout an educational organization to deconstruct current schemata regarding schooling and schooling practices may open imaginations to new alternatives. As Rowling states, "We do not need magic to change the world, we carry all the power we need inside ourselves already: we have the power to imagine better" (p. 7).

\section{Author's Note on Research Methodology}

The "applied qualitative research" of this study (Bogdan \& Biklen, 1992, p. 199) was conducted largely for application in this one setting to advance the learning and development of the ideas in this one school. In this sense, the study is action research. The researcher and the school staff set out to be reflective, observant, and analytical of their own practice in order to learn from their work and make future adjustments in their thoughts and actions. Action research "is designed to bring about social change" (Bogdan et al., 1992, p. 223). The social change desired involved the development of the school's assessment practices in order to enhance students' learning and to invite community understanding of the school's program and children's learning processes. Action research was used in this setting to "expose the practice in order to change it" (p. 229). In this case, the research was used to make transparent and examine the various educational and political dimensions of an alternative assessment process.

One of the challenges in developing assessment and accountability processes is designing means that capture the complexity of student learning and the situations or programs that are to encourage this learning (Bransford et al. 2000; Pelligrino et al., 2001). The same challenge is true for capturing how this alternative assessment and accountability process was developed at the school in this study.

A case study is one means of capturing the complexity of a situation (Stake, 1995). It includes rich descriptions that engage the reader in a "vicarious experience of having been there" (Merriam, 2009, p. 258). Descriptions are provided less for the representation of truth and more for discovering meaning (Eisner, 1981). In this sense, readers are provided with "raw material" upon which to make their 
own conclusions about the nature of the activity (Stake, 1995, p. 102). The researcher's task is not to convince, but to present a plausible argument (Bogdan et al., 1992, p. 190; van Manen, 1990, p. 65). This is similar to James Popham's (2001) suggestions to administrators for rethinking assessment and accountability, "...the administrator must assemble a solid array of accurate, convincing evidence culled from a variety of sources" (p. 142). Popham encourages school administrators to 'build a powerful case' much like Perry Mason as the renowned U.S. TV lawyer.

The goal here is to present a description of an alternative assessment process that engages the reader vicariously for the purposes of "open communication about education with the public" (Clark, 1990, p. 337). This can illuminate the complexity of the educational process and identify areas not previously considered by reformers and educators working to create more powerful and productive learning and assessment opportunities.

\section{Researcher Role}

In action research, the researcher is the primary instrument of data gathering (Stake, 1995, p. 29). This participant-observer role can vary from peripheral involvement to complete involvement in the activity being recorded and studied (Spradley, 1980, p. 58). The Adlers (1987) distinguish between an active member role and that of a complete member, "sharing a common set of experiences, feelings and goals" (p. 67). In this work, the author was a complete member, serving as the principal of the school at the time of the events and was intimately involved in the effort being reported and studied.

\section{Data}

The data for this study consisted of field notes taken by the researcher (principal), participants' collected remembrances (Bartlett, 1932) including notes and charts gathered during the planning sessions, and field notes from staff members engaged in this process. The notes and other documents focus on assessment events and focus- group discussions surrounding the development of the assessment process. They come from the school handbook, student debriefing interviews, family/community surveys, and school newsletters to the school community. These were used to present the process of development of the alternative assessment process and to construct the narrative of one of the assessment events, which is presented here to illustrate what happened at the assessment events held at the school involved in this research.

The quality of evidence in qualitative research continues to be debated. Lincoln (2002 as cited in Freeman et al., 2007) developed standards of evidence for qualitative research. These standards can be used to assess the quality of the research presented here. First, researchers should be closely involved in the setting and action. The researcher here was intimately involved in the role of school principal as revealed previously. Second, there should be distance from the "phenomenon to permit recording action and interpretations free of the researcher's own stake." These data were reviewed and the analysis was conducted two years after the researcher moved from the school and community and no longer served in an administrative capacity in schools. Third, "claims should be based on an adequate selection of the total corpus of data." While much of the data is presented here to provide a context for the action research project, the specific event presented in the narrative came from one event of the many assessment activities that occurred at the school. This event was chosen for its revelation of the many competing tensions and possibilities in alternative assessment. The cognition, learning, and assessment literature was then used to formally analyze the significance of the process. This is presented in section III, Going Public: Developing Common Conceptions.

The fourth area Lincoln urges, is that the data partly come from "publicly accessible records." At the time of the project, some of the documents (School Handbook and newsletters) cited were publicly accessible through the school website, newsletters or school board minutes. The original documents remain in the researcher's database. The school has continued to develop and modify its work; however, a recent review of the school website reveals a strong relationship with what is presented in the public documents cited. Lastly, Lincoln states that the analysis of the data should include a description of "concrete phenomenon" as well as "inferences and interpretations" (Freeman, de Marrais, Preissle, Roulston, \& St. Pierre, p. 28). How well this was done in the analysis and discussion section, is certainly a matter for the reader to conclude.

\section{Timeline}

This process took place over a period of two years with planning and pilot efforts conducted in the first year. 
During the summer, the staff worked to formalize and document the components of the process for inclusion in the school handbook. The process was formally launched with the students and the school community in the fall of the second year. The event presented here took place mid-year of the second year.

\section{About the Author}

VIKI L. MONTERA is currently the Co-Director of the CANDEL joint doctoral program in Educational Leadership between Sonoma State and the University of California at Davis. She teaches courses on leadership and change; curriculum, instruction and assessment and educational politics and policy. Her research interests are curricular change, organizational reform, professional learning communities, teacher dialogue, and the development of democratic learning environments.

Email:vlmontera@sonoma.edu

\section{REFERENCES}

Adler, P. A., \& Adler, P. (1987). Membership roles in field research. Newbury Park, CA: Sage Publications.

Au, W. (2007). High stakes testing and curricular control: A qualitative metasynthesis. Educational Researcher, 36(5), 258-267.

Baker, E. L. (2007). The end(s) of testing. Educational Researcher, 36(6), 309-317.

Bartlett, F. C. (1932). Remembering: A study in experimental and social psychology. Cambridge, England: Cambridge University Press.

Bereiter, C. \& Scardamalia, M. (1989). Intentional learning as a goal of instruction. In L. Resnick (Ed.), Knowing, learning and instruction: Essays in honor of Robert Glaser. Hillsdale, NJ: Lawrence Erlbaum Associates.

Black, P. \& William, D. (1998). Assessment and Classroom Learning. Assessment in Education: Principles, Policy \& Practice, 5(1), 7-74.

Bogdan, R. C. \& Biklen, S. K. (1992). Qualitative research for education: An introduction to theory and methods. Boston, MA: Allyn and Bacon.

Bransford, J., Brown, A. \& Cocking, R. (Eds.), (2000). How people learn: Brain, mind, experience and school. Washington, D.C.: National Academy Press.

Broadfoot, P. \& Black, P. (2004). Redefining assessment? The first ten years of assessment in education. Assessment in Education: Principles, Policy \& Practice, 11(1), 7-26.

Brown, A. L. \& Palincsar, A. S. (1989). Guided cooperative learning and individual knowledge acquisition. In L. Resnick (Ed.), Knowing, learning and instruction: Essays in honor of Robert Glaser (pp. 393-451). Hilsdale, NJ: Lawrence Erlbaum Associates.

Bruner, J. (1990). Acts of meaning. Cambridge, MA: Harvard University Press.

Clark, C. M. (1990). What you can learn from applesauce: A cast of qualitative inquiry in use. In E. Eisner \& A. Peshkin (Eds.), Qualitative inquiry in education: The continuing debate (pp. 327-338). New York: Teachers College Press.

Cobb, P. (1998). Learning from distributed theories of intelligence. Mind, culture, and activity, 5(3), 187-204

Cremin, L. A. (1975). Public education and the education of the public. Teachers college record, 77(1), 1-12.

Cizek, G. J. (2001). More unintended consequences of highstakes testing. Educational Measurement: Issues and Practice, Winter, 19-27.

Edelson, D. C., Gordin, Douglas N., \& Pea, Roy D. (1999). Addressing the challenges of inquiry-based learning through technology and curriculum design. The Journal of the Learning Sciences, 8(3/4), 391-450.

Eisner, E. (1981). On the differences between scientific and artistic approaches to qualitative research. Educational researcher, 10(4), 5-9

Freeman, M., de Marrais, K., Preissle, J., Roulston, K. \& St. Pierre, E. A. (2007). Standards of evidence in qualitative research: An incitement to discourse. American Educational Research Association, 36(1), 25-32.

Friedman, T. (2005). The world is flat: A brief history of the twentyfirst century. New York: Farrar, Straus, and Giroux. 
Furtak, E. M., Ruiz-Primo, M. A., Shemwell, J. T., Ayala, C. C., Brandon, P. R., Shavelson, R. J., \& Yin, Y. (2008). On fidelity of implementing embedded formative assessments and its relation to student learning. Applied measurement in education. 21(4), 360-98.

Glickman, C. \& Alridge, D. (2001). Going public: The imperative of public education in the twenty-first century. In A. Lieberman and L. Miller (Eds.), Teachers caught in the action: Professional development that matters, (pp.12-22). New York: Teachers College Press.

Gonzales, N., Moll, L., \& Amanti, C. (2005). Funds of knowledge: Theorizing practices in households, communities, and classrooms. Mahwah, N.J.: Lawrence Erlbaum Associates \& Publishers.

Gonzales, N., Andrade, R., Civil, M., \& Moll, L. (2001). Bridging funds of distributed knowledge: Creating zones of rractices in mathematics. Journal of Education for Students Placed at Risk, 6 (1 \& 2), 115-132.

Heckman, P. E. (1993). School restructuring in practice: Reckoning with the culture of school. International Journal of Educational Reform, 2(3), 263-272.

Heckman, P. E. \& Montera, V. L. (2009). School reform: The flatworm in the flat world: From entropy to renewal through indigenous invention. Teachers college record, 111(5), 13281351.

Honig, M. I. (2006). Complexity and policy implementation: Challenges and opportunities for the field. In M. I. Honig. (Ed.), New directions in education policy implementation: Confronting complexity (pp. 1-23). Albany: State University of New York Press.

Koretz, D. (2008). Measuring up: What educational testing really tells us. Cambridge, MA: Harvard University Press.

Langer, E. (1997). The power of mindful learning. Cambridge, MA: Perseus Books.

Lemann, N. (1999). The big test: the secret history of the American meritocracy. New York: Farrar, Straus and Giroux.

McNeil, L. (2000). Contradictions of school reform: Educational costs of standardized testing. New York: Routledge Falmer.

McNeil, M. \& Klein, A. (September 28, 2011). Obama outlines NCLB flexibility: Plan waives cornerstone provisions of law. Education Week 31(5), 20-21.

Merriam, S. B. (2009). Qualitative research: A guide to design and implementation. San Francisco, CA: Jossey-Bass.

Mintrop, H. \& Sunderman, G. L. (2009). Why high stakes accountability sounds good but doesn't work - And why we keep on doing it anyway. University of California, Los Angeles: Civil Rights Project/Proyecto Derechos Civiles.

Pelligrino, J. W., Chudowsky, N., \& Glaser, R. (Eds.). (2001). Knowing what students know: The science and design of educational assessment. Washington, D.C.: National Academy Press.

Pintrich, P. R. (2002). The role of metacognitive knowledge in learning, teaching, and assessing. Theory into Practice, 41(4), 219-225.

Popham, W. J. (2001). The truth about testing: An educator's call to action. Alexandria, VA: Association for Supervision and Curriculum Development.

Ravitch, D. (2010). The death and life of the great American school system: How testing and choice are undermining education. New York: Basic Books.
Rowling, J. K. (2008). The fringe benefits of failure and the importance of imagination. Harvard Magazine.com. Retrieved April 23, 2009 from http://harvardmagazine.com/commencement/the-fringebenefits-failure-the-importance-imagination

Sacks, P. (1999). Standardized minds: The high price of America's testing culture and what we can do to change it. Cambridge, MA: Perseus Publishing.

Shavelson, R., Ruiz-Primo, M. A., Li, M., \& Ayala, C. C. (August, 2003). Evaluating New approaches to assessing learning (CSE Report 604). University of California, Los Angeles: Center for the Study of Evaluation (CSE).

Shepard, L. A. (2000). The role of assessment in a learning culture. Educational Researcher, 29(7), 4-14.

Sirotnik, K. A. (2002). Promoting responsible accountability in schools and education. Phi Delta Kappan, 83(9), 662-673.

Smith, M. L. (2004). Political spectacle and the fate of American schools. New York: Routledge Falmer.

Spillane, J. P., Reiser, B. J., \& Gomez, L. M. (2006). Policy implementation and cognition: The role of human, social, and distributed cognition in framing policy implementation. In M. I. Honig. (Ed.), New directions in education policy implementation: Confronting complexity (pp. 47-64). Albany: State University of New York Press.

Spradley, J. P. (1980). Participant observation. Ft. Worth, TX: Holt, Rinehart and Winston, Inc.

Stake, R. E. (1995). The art of case study research. Thousand Oaks, CA: Sage Publications.

Sternberg, R. J. (October, 1997). The Concept of Intelligence and Its Role in Lifelong learning and Success, American Psychologist, 52(10), 1030-1037.

Tyack, D., \& Cuban, L. (1995). Tinkering toward utopia. Cambridge, Massachusetts: Harvard University Press.

van Manen, M. (1990). Researching lived experience: Human science for an action sensitive pedagogy. Ontario, Canada: The Althouse Press, Faculty of Education, The University of Western Ontario.

Vygotsky, L. (1978). Mind in society: The development of higher psychological processes. Cambridge, MA: Harvard University Press.

Weaver-Hightower, M. B. (2008). An ecology metaphor for educational policy analysis: A call to complexity. Educational Researcher. 37(3), 153-167.

Wertsch, J. V. (1998). Mind as action. New York: Oxford University Press. 